\title{
Unveiling Pre-service Language Teachers' Conceptualizations of Teachers of English through Metaphors
}

\author{
Suzan Kavanoz \\ Correspondence: Suzan Kavanoz, Yıldız Technical University, Turkey. \\ Received: June 23, 2016 Accepted: July 7, $2016 \quad$ Online Published: July 28, 2016 \\ doi:10.11114/jets.v4i10.1690 \\ URL: http://dx.doi.org/10.11114/jets.v4i10.1690
}

\begin{abstract}
The present research aimed at conducting an analysis of metaphors Turkish pre-service language teachers generated about English as a Foreign Language (EFL) teachers. This study also examined whether and how the metaphors created by teacher candidates at different phases of their education demonstrated variation. The data gathered from 94 participants were analyzed using the taxonomy of metaphors developed by Oxford and her colleagues (1998). The analysis revealed a gradual decline in participants' views of teacher as a professional responsible for social order and cultural transmission as they became more acculturated into the profession. The few occurrences of learner-centered metaphors and the predominance of teacher-centered metaphors in the initial years were replaced with more learner-centered metaphors. The results supported the initial assumption about the impact of class level differences on prospective teachers' thinking about teaching and learning. The transformation in participants' perception is indicative of how their professional identity is perpetually constructed and reconstructed during teacher preparation.
\end{abstract}

Keywords: metaphor analysis, pre-service language teachers, teacher identity, teacher development

\section{Introduction}

One of the most indispensable components of schooling and education is teachers. Teachers have great responsibilities in carrying out effective instructional practices and provide their students with opportunities to develop themselves as human beings and learners (Ben-Peretz, Mendelson \& Kron, 2003). Correspondingly, a primary aim of teacher education programs is to enable student teachers to develop professional knowledge and skills they need, in order to successfully fulfill the tasks assigned to them. It is now well documented that on entry to teacher education programs, pre-service teachers bring with them a set of experiences, assumptions, and beliefs about teaching and learning by virtue of being exposed to at least twelve years of schooling (Lortie, 1975; Feiman-Nemser \& Remillard, 1996). Knowles (1992) posits that owing to experiences and interactions with teacher educators, teacher candidates construct different conceptualizations about the role of the teacher and an image of their own self. Teachers' self-image, which influences their instructional strategies and decisions in the classroom, is highly determined by their perception of themselves (Combs, Blume, Newman \& Wass, 1974).

It is suggested that beginning teachers' decisions in the classroom setting are largely affected by their thinking and for this reason teacher education must begin by examining the teaching-self (Bullough, 1997). Teacher identity, which bears multiple interpretations (Olsen, 2008), represents the ways teachers make sense of themselves and the images they present to others (Alsup, 2006). Developing a strong identity is a key variable for teachers' occupational commitment (Darling-Hammond \& Brandsford, 2005) and their capacity to perform the profession effectively (Day, 2002). Since self-identity is a pivotal component of teacher preparation (White \& Lemieux, 2015), it is important to examine pre-service teacher candidates' professional identity and unearth their self-image as teachers (Beijaard, Verloop, \& Vermunt, 2000). This can be achieved by engaging them in the process of articulating their beliefs before completing their education program (Barone, Blanchard, Casanova, \& McGowan, 1996). Due to the complex nature of teacher identity, metaphors have been abundantly used as a cognitive tool for examining various aspects of teacher identity (e.g. Cortazzi \& Jin, 1996; Martinez, Sauleda \& Huber, 2001; Thomas \& Beauchamp, 2011).

Yet, to date little work has been done in attempting to identify and differentiate the cognitive perspectives of pre-service EFL teachers as evidenced through an analysis of metaphor based on their year level in Turkish context. In order to fill this gap, the present study focuses on the metaphors about English as a foreign language (EFL) teachers produced by EFL pre-service teachers to enable teacher educators to uncover pre-service teachers' representations of themselves 
(Kramsch, 2003). It is also essential to define what EFL teacher means in different educational settings from a point of view of pre-service teachers (Borg, 2006). Understanding the development of pre-service language teachers over the course of a teacher education program will help teacher educators to provide pre-service teachers with necessary training and support.

The present study aims at conducting an analysis of metaphors about EFL teachers created by Turkish pre-service language students using a typology of metaphors developed by Oxford and her colleagues (1998). This study also examines whether and how the metaphors generated by teacher candidates at different stages of their education show variation. The findings obtained will contribute to a better portrayal of development of language teacher identity in Turkish context.

The present enquiry conducted at a Turkish higher education institution raises the following questions:

1. What metaphors do Turkish pre-service language teachers generate to describe teachers of English?

2. What differences can be observed in the metaphors chosen by pre-service EFL teachers in terms of their year level?

\subsection{Literature Review}

Teachers continuously develop their teaching identities during the process of becoming a teacher (Clarke, 2008). The concept of "becoming a teacher" refers to how teacher candidates define themselves as a teacher (Lortie, 1975; Danielewicz, 2001) as well as how a teacher perceives his or her position as a teacher (Clarke, 2008). While teacher candidates make decisions about the type of teacher they want to become, they are involved in identity development. Developing a strong sense of professional identity is central for performing of the profession competently (Thomas \& Beauchamp, 2011). Olsen (2008), in a similar vein, asserts that teacher identity is useful as a research framework because teachers are viewed as whole persons "who continually reconstruct their views of themselves in relation to others, workplace characteristics, professional purposes, and cultures of teaching" (p.5).

Recent literature on teacher education draws attention to the significance of identity in teacher development (Beauchamp \& Thomas, 2009; Olsen, 2008; Sachs, 2005; Thomas \& Beauchamp, 2011). Qualitative research designs have been substantially utilized in order to explore pre-service teachers' professional identity, such as interviews and narratives (Farrell, 2011; Goldstein, 2005), drawings (Beltman,Glass, Dinham, Chalk \& Nguyen, 2015; Brand \& Dolloff; 2002; Freer \& Bennet, 2012), and metaphors (Buchanan, 2015; Leavy, McSorley \& Boté, 2007; Thomas \& Beauchamp, 2011; Yeşilbursa, 2012). In educational discourse, metaphors play a salient role in conceptualizing and reflecting upon the nature of teaching and learning. Specifically, over the past three decades, researchers and teacher educators have been interested in utilizing metaphors as a cognitive tool to discern how teachers perceive schooling, coursebooks, foreign language classroom, curriculum, teachers, and teaching (Kesen, 2010; İnceçay, 2015; Seferoğlu, Korkmazgil \& Ölçü, 2009; Tobin, 1989, 1990; Wallace 2001). On the grounds that metaphors make connections between personal beliefs and educational theories (Leavy et al. 2007).

A metaphor is defined as a "figure of speech in which a word or phrase literally denoting one kind of object or idea is used in place of another by way of suggesting a likeness or analogy between them" (as cited in Isenberg 1963, p.609). Lakoff and Johnson (1980a) argue that humans live by metaphor because "metaphors are necessary for making sense of what goes on around us" (p.186). Likewise, Oxford, et al. (1998) suggest that metaphor "has the power to enhance the subject's understanding of educational problems and thus increase perspective-consciousness" (p.5). Through metaphors, it is plausible to show that abstract concepts can be expressed with images that are more concrete (Oxford, et al., 1998). Thus, metaphors about teaching provide insights into the professional development of new teachers as they formally learn to teach through theories, develop teaching skills, and enter into the profession (Knowles, 1994).

Studies of metaphor have particularly gained momentum after the publication of Lakoff and Johnson's (1980a) groundbreaking book Metaphors We Live By. Lakoff and Johnson (1980a) proposed that the nature of human conceptual system is essentially metaphorical (Lakoff \&Johnson, 1980b). Since then, metaphors have become a cognitive tool to enquire into how teachers conceptualize different elements of education such as students, curriculum and teaching as well as their profession (Tobin, 1990). It is postulated that the study of teacher metaphors is appropriate for exploring relationships between contextual variables and teachers' professional identity (Ben-Peretz, Mendelson \& Kron, 2003; Tobin, 1990) because the examination of metaphorical images serves as a means to make explicit teachers' underlying assumptions and beliefs concerning subject matter and their own roles in classrooms (Dolloff,1999).

There is substantial research on the examination of metaphors used by pre-service teachers and practicing teachers to express their underlying beliefs about schooling experiences, teaching, professional self and subject areas (Ben-Peretz, Mendelson, and Kron, 2003; Leavy et al. 2007; Mahlios \& Maxson, 1998; Martinez et al., 2001; Saban, Koçbeker \& Saban, 2007). Metaphor studies can generally be classified in two categories; one line of research focuses on the 
identification of metaphors both practicing and pre-service teachers endorse regarding teaching, learner and their roles as a teacher (Nikitina\& Furuoka, 2008; Saban et al. 2007, Seferoğlu et al. 2009; Zapata \&Lacorete, 2007) while the other thread tracks the development of metaphors in the light of academic and field-based experiences (Alger, 2009; Leavy et al., 2007; Şimşek, 2014).

In previous research on metaphor studies with pre- and in-service language teachers in Turkish context, Seferoğlu et al. (2009) aimed to elicit metaphors and similes employed by pre-service (junior and senior students) and in-service English language teachers in order to figure out the relationship between the concept of teacher and the metaphors the participants used. The researchers used three categories in order to analyze the data: autocratic teacher, democratic/participatory teacher, laissez-faire teacher. The results showed that the only significant difference among responses of the three groups of participants was the percentage of metaphors to denote teacher as a facilitator. This category was very high within in-service teachers compared to pre-service teacher groups. The overall distribution of metaphors used by three groups of participants demonstrated that while all three groups valued democratic/participatory teacher the most, in-service teachers showed the highest tendency towards this category. Only a small percentage of metaphors could be categorized under laissez-faire teacher category that reflected shared teacher student power depending on mutual respect and expertise as well as recognition of individual learning differences. On the other hand, the view of teacher as an autocratic leader was frequently acknowledged by senior year participants. They concluded that in-service teachers get a more learner-centered perspective as they become experienced. Likewise, the mixed-method study by Oktay and Osam (2013) compared the metaphors expressed by English language instructors and freshman students from the engineering and mathematics departments using the taxonomy suggested by Oxford et al. (1998). Language teachers were found to have a balanced approach operating between learner-centered and teaching centered approaches, relying more heavily on learner-centered approach. In both studies, both pre-service and in-service language teachers seemed to assume a learner-centered approach.

In Western contexts, where there is usually more emphasis on constructivist approaches to learning with more focus on the active learner within the teaching learning process (Jones \& Brader-Araje, 2002), the researchers analyzed metaphors using different taxonomies. However, contrary to results obtained in Turkish context, the researchers documented inconsistent findings. In order to define the teaching process and the role of language teachers, Oxford et al. (1998) explored how the "teacher" concept is viewed based on metaphors that came from student, former-student, and teacher narratives and texts by educational specialists. They identified fourteen metaphors such as teacher as manufacturer, teacher as conduit, teacher as nurturer, teacher as acceptor, teacher as competitor, teacher as repeater,teacher as lover or spouse, teacher as learning partner, teacher as hanging judge, teacher as scaffolder, teacher as doctor, teacher as entertainer, teacher as mind-and-behavior controller, teacher as delegator which they classified within a four-part typology: Social Order, Cultural Transmission, Learner-Centered Growth and Social Reform. Even though they found a variety of teacher-role metaphors regarding social order, cultural transmission, and learner-centered growth, participants did not tend to discuss social order perspective as frequently as the other three perspectives. Whenever this perspective was mentioned, the participants strongly advocated a vision of a teacher acting as a learning partner. On the other hand, Martinez et al. (2001) attempted to identify prospective and practicing teachers' implicit theories of learning as represented by metaphors within a conceptual space determined by explicit theories falling into three main dimensions of the learning space (1) behaviorist/ empiricist perspective, the (2) cognitive/constructivist perspective, and the (3) situated/socio-historic perspective. They reported that prospective language teachers formulated many more constructivist metaphors than experienced teachers and prospective teachers on the other hand showed less tendency to describe learning in terms of behaviorist metaphors than experienced teachers.

Likewise, Zapata and Lacorete (2007) explored the metaphorical language used by 64 Spanish and English as a foreign language pre- and in-service teaching assistants and instructors for their conceptualization of L2 teachers and students. Except for a group of EFL teachers, the results demonstrated the prevalence of the conduit metaphor in most participants' conceptualizations despite the variations in their experiences and academic and cultural backgrounds. Majority of the participants preferred to create metaphors within the cultural transmission perspective. The second most popular category was learner-centered growth while there was less emphasis on social order and social reform perspectives. In De Guerrero and Villamil's (2001) study, the ESL teachers in Puerto Rico produced 28 metaphors, which were organized into nine general categories. The three most popular categories presented contrasting views among the participants, as they conceptualized the ESL teacher as (1) a cooperative leader, (2) a knowledge provider, and (3) a challenger or agent of change. In the Asian educational context, Nikitina and Furuoka (2008) examined metaphors about language teachers created by 23 Malaysian university students in order to determine to what extent the metaphors generated by students fit into the four philosophical perspectives on education outlined by Oxford et al. (1998). Their participants mostly described the language teacher as a nurturer, entertainer, or giver followed by the view 
of the teacher as conduit of knowledge, competitor, mind-and-body controller, and hanging judge. Regarding four aspects of education, the majority of the metaphors were categorized under the learner-centered growth, followed by the cultural transmission and the social order. It was found that the language classroom was perceived as the "teacher's world" where the teacher acted as a leader and an organizer.

The other strand of research involves studies in which the metaphors generated by the participants were considered as indications of their development. Using an online survey instrument, Alger (2009) asked secondary teachers (teaching English, Social Studies, Maths, Physical Education) to choose teaching metaphors that match their teaching on three levels: envisioned teaching metaphor prior to their initial entry to the profession, current teaching metaphor and desired teaching metaphor. Her results revealed that there was a change in their conception of teaching over their career span. While very experienced teachers came to the profession with teacher-centered conceptual metaphors, there was a reduction in teacher-centered conceptual metaphors and an increase in student-centered conceptual metaphors that represented current practice and desired practice. She attributed this shift towards student-centered metaphors to professional development or changes in school culture. Similarly, Leavy et al. (2007) examined Irish and American elementary prospective teachers' beliefs about teaching and learning at three levels: on entry to teacher education programs, after their enrollment in academic courses and finally after they gained school based experiences. The classification of metaphors according to the conceptual categories suggested by Martinez et al. (2001) indicated a small drop in the number of behaviorist, situative and self-referential metaphors, and a noticeable increase in the metaphors labelled as constructivist. The authors argue that these changes result from the exposure to constructivist principles in methodology courses as well as the participants' field based experiences. Şimşek (2014) used Low and Cameron's methodology (1999) and the framework of Oxford et al. (1998) in order to investigate Turkish pre-service EFL teachers' beliefs before and after taking the course, "Approaches to ELT" in order to find out whether taking the course influences their conceptualizations. The participants in this context exhibited a move from the traditional conceptions of teacher as molder/knower to the contemporary conception of teacher as a facilitating partner. None of the participants offered metaphorical evidence regarding the participatory view of teaching.

The metaphor studies that strive to shed light on the development of pre-service teachers' identity have been found useful for unmasking the changes in pre-service teachers' beliefs about teaching and learning that result from their engagement in pedagogical subjects as well as their school practice experiences. Along similar lines, discovering how teacher metaphors develop through time is likely to imply the extent of change in teacher perceptions and development (Buchanan, 2015) and hence to offer more information about the growth in their professional identity (Thomas \& Beauchamp, 2011)

\section{Research Design}

Eliciting pre-service teachers' metaphorical images in a qualitative professional identity study will allow participants and researchers to delineate the mechanism of identity development vividly (Thomas \& Beauchamp, 2011). Considering this, the main purpose was to examine ways in which pre-service EFL teachers conceptualize EFL teacher through metaphors and how these conceptualizations contribute to gauging their emerging identities as EFL teachers. The data were analyzed using a general inductive approach to qualitative data analysis (Miles \& Huberman, 1984).

\subsection{Participants}

The research was conducted among the $2^{\text {nd }}, 3^{\text {rd }}$ and $4^{\text {th }}$ grade pre-service teachers enrolled in English Language Teaching (ELT) Department at a state university in Turkey. This investigation was performed with 94 students chosen according to convenience sampling method among 284 students enrolled in ELT program. All three cohorts of students were selected using non-probability sampling strategy. Participants were included in this study based on their academic knowledgebase and school practice experiences that would allow them to provide information relevant to the main objectives of the research (Patton, 1990). During their teacher education program, the participants are introduced to methodology courses such as Approaches and Methods in Language Teaching and Instructional Principles and Methods in the second year. In the third year, methodology courses are intensified and students take a number of pedagogical courses such as Teaching English to Young Learners, Teaching Language Skills, and ELT Methodology. Fourth year is marked by the commencement of school practices that enable pre-service EFL teachers to gain experiences through observations of language classes at different levels and micro-teaching practices. School practice is accompanied with pedagogical courses such as Individual Differences in Teaching and Guidance. The purpose of the research was announced to the participants and they were told that the submission of the metaphors was not related to any assessments in the courses given by the researcher. It was assumed that turning in the metaphors indicated their consent to participate in this research. The distribution of respondents according to their class levels and genders are presented in Table 1. 
Table 1. Demographic information about the participants

\begin{tabular}{llrr}
\hline Participants & & Frequency & \multicolumn{2}{c}{ Percentage } \\
\hline Class Level & Sophomore & 24 & 25.5 \\
& Junior & 46 & 48.9 \\
& Senior & 24 & 25.5 \\
& Total & $\mathbf{9 4}$ & $\mathbf{1 0 0}$ \\
\hline Gender & Male & 32 & 34.0 \\
& Female & 62 & 66.0 \\
& Total & $\mathbf{9 4}$ & $\mathbf{1 0 0}$ \\
\hline
\end{tabular}

\subsection{Data Collection}

Metaphors were obtained from participants by means of open-ended questions. Data were collected near the end of spring semester during 2014-2015 academic year in the last 30 minutes of each course. During one session of their courses, the participants were presented with definitions and examples of metaphors. As the main objective of the study was to elicit their own metaphors about a pre-determined construct, statement forms were prepared. First part of the form included personal information related to their year level and gender and the second part included the completion of the sentence "An EFL teacher is like...because..." The preposition like is used in order to make the participants create the relationship and emphasize the resemblance between metaphor topic (EFL teacher) and metaphor vehicle (the required response). They were also required to complete their sentences using 'because' as a conjunction in order to clarify the likeness (Saban et al., 2007). This clarification part, rather than the metaphor vehicle, allowed interpretation and classification of the metaphors into categories (Nikitina \& Furuoka, 2008).

\subsection{Data Analysis}

Following the methodology of metaphor analysis (Moser, 2000), data analysis process started with separately identifying the metaphor from each participant. As stated in Moser (2000), metaphor analysis is essentially a qualitative research methodology related to content analysis. Berelson (1952) defines content analysis as "a research technique for the objective, systematic, and quantitative description of the manifest content of communication" (as cited in Lombard, Synder-Duch \& Bracken, 2002, p.18). Using an iterative approach, the metaphors were first labeled and sorted. Since it was not possible to obtain an analyzable valid metaphor from all the participants, nine forms were eliminated from 96 metaphors. These-excluded forms either gave a description of the profession or lacked the required justification (Saban et al., 2007). Following these stages, the metaphors were categorized according to themes that emerged as possible categories from the responses. The researcher developed inductive codes by directly examining the data and reviewing previous literature during this open coding phase. Once all the data were coded and tabulated, thematic categories were reviewed. At the classification step, the metaphors were organized according to conceptual categories by focusing on the predominant features of the metaphors.

In order to add validity and credibility to this investigation, the author of this paper and an expert in applied linguistics independently coded and categorized all the metaphors according to their conceptual categories. The coder was familiar with research on metaphors and had expertise in qualitative data analysis. In several cases where consensus was not reached, discrepancies were discussed until agreement was reached. An overall reliability of 0.92 was obtained, which is above the suggestion that overall inter coder reliability should approach 0.90 (Miles and Huberman, 1994). In the last stage, which required analysis of data quantitatively, SPSS 21 program was used to calculate frequencies and percentages of the metaphors in each category. The final part of the analysis involved categorizing the emergent metaphors using the taxonomy by Oxford et al. (1998) running chi-square and Fisher's exact test to determine whether there is a significant difference across the three different class levels and carrying out cluster analysis to have a more precise interpretation of the data.

\subsection{Framework for the Study}

In a large-scale study on metaphors, Oxford et al. (1998) posited that all the metaphors teachers generate to make sense of their own beliefs and experiences could be interpreted using four philosophical viewpoints on education: Social Order, Cultural Transmission, Learner-Centered Growth, and Social Reform. This taxonomy has been considered one of the most comprehensive approaches used for classification of metaphors in foreign language education and adapted by a number of researchers (e.g. Farrell, 2011; de Guerro \& Villamil, 2001; Nikitina \& Furuoka, 2008; Saban et al. 2007, Şimşek, 2014). For the purpose of this inquiry, Oxford et al.'s (1998) four-part typology deemed most suitable.

\section{Findings}

The research question asked participants to express their metaphors about English language teachers. Pre-service teacher's metaphors were multidimensional signifying subject matter knowledge, pedagogical knowledge, and affective domains. Differences were observed in the metaphors used by pre-service EFL teachers with varying amount of 
academic knowledgebase and school-based practices depending on their year level. In the following section, 11 conceptual categories deduced from the metaphors are introduced and their main characteristics are given. The analyses regarding the effects of the participants' class level on metaphorical representations are presented, which are followed by example metaphors for each category. The quotes were chosen not only because of their power to convey the essence, but also due to their poignant nature.

\subsection{Main Conceptual Categories}

After the elimination of statements that do not reflect metaphors, the analysis was carried out with 87 metaphors. Second year students $(\mathrm{N}=24)$ generated 25 metaphors, while third year students $(\mathrm{N}=46)$ produced 39 metaphors, and fourth year students $(\mathrm{N}=24)$ provided 23 metaphors. Even though the frequencies of metaphors might appear uneven, it was seen that three groups were similar regarding the absolute number of metaphors formulated $(1.04,0.84,0.96$ per person in each group respectively).

The analysis of 87 metaphors through metaphor analysis yielded 11 conceptual metaphors, which reflected EFL pre-service teachers' conceptualizations of their role. The metaphors were EFL teacher as a source and provider of knowledge, EFL teacher as a facilitator, EFL teacher as a an artist, EFL teacher as a craftsperson, EFL teacher as a direction setter, EFL teacher as a superior authoritative, EFL teacher as a change agent, EFL teacher as a nurturer, EFL teacher as a counselor, EFL teacher as an entertainer, EFL teacher as a cooperative leader. The following table displays the metaphors and frequencies of their mentions by the participants and how the produced metaphors are distributed among different year levels.

Table 2. Conceptual categories of metaphors and their distribution among year levels

\begin{tabular}{|c|c|c|c|c|c|c|c|c|}
\hline \multirow[t]{2}{*}{ Metaphor } & \multicolumn{2}{|c|}{ Sophomore } & \multicolumn{2}{|c|}{ Junior } & \multicolumn{2}{|c|}{ Senior } & \multicolumn{2}{|c|}{ Total } \\
\hline & $F$ & $\%$ & $F$ & $\%$ & $F$ & $\%$ & $F$ & $\%$ \\
\hline Source and provider of knowledge & 11 & 44.0 & 16 & 41 & 5 & 21.7 & 32 & 36.8 \\
\hline Facilitator & 3 & 12.0 & 4 & 10.3 & 3 & 13.0 & 10 & 11.5 \\
\hline Artist & 1 & 4.0 & 1 & 2.6 & 0 & 0.0 & 2 & 2.3 \\
\hline Craftsperson & 1 & 4.0 & 2 & 5.1 & 1 & 4.3 & 4 & 4.6 \\
\hline Direction setter & 5 & 20.0 & 2 & 5.1 & 4 & 17.4 & 11 & 12.6 \\
\hline Superior Authoritative & 1 & 4.0 & - & - & 1 & 4.3 & 2 & 2.3 \\
\hline Change Agent & 2 & 8.0 & 3 & 7.7 & - & - & 5 & 5.7 \\
\hline Nurturer & 1 & 4.0 & - & - & 1 & 4.3 & 2 & 2.3 \\
\hline Counselor & - & - & 2 & 5.1 & - & - & 2 & 2.3 \\
\hline Entertainer & - & - & 3 & 7.7 & 3 & 13.0 & 6 & 6.9 \\
\hline Cooperative Leader & - & - & 6 & 15.4 & 5 & 21.7 & 11 & 12.6 \\
\hline Total & 25 & 100 & 39 & 100 & 23 & 100 & 87 & 100 \\
\hline
\end{tabular}

3.1.1 Teacher as a Source and Provider of Knowledge

There were 32 metaphors under the category of teacher as a source and provider of knowledge, constituting $36.8 \%$ of the whole data set. The following five metaphors were dominant: i. guide appears four times $(12.5 \%)$, ii. mother occurs three times (9.4\%), iii. culture and its derivations (e.g. culture river, culture ambassador) appear three times (9.4\%), iv. father is used two times (6.3\%). In this classification of metaphors, the teacher is viewed as both the source (e.g., garden, virus, dream, alien) and the provider of knowledge (e.g. guide, mother, father), whereas the students are reflected as passive recipients. While second year students predominantly attributed the role of a provider and source of knowledge to the EFL teacher, junior students seemed to find this role less important compared to their younger counterparts. However, a dramatic decrease is observed regarding this role when senior students' metaphors are analyzed. For this group, the teacher is not acknowledged as a source and provider of knowledge far too much. The following statements demonstrate metaphors that reflect teacher's role as a source and provider of knowledge.

“An EFL teacher is like an ocean because it continuously replenishes itself and its knowledge never ceases." (2 ${ }^{\text {nd }}$ year, F)

"An EFL teacher is like a garden that harbors a variety of fruit trees because EFL teachers must not only know the language they teach, but they also need to know their students'language and bear a number of qualities." ( $3{ }^{\text {rd }}$ year, F)

"An EFL teacher is like a virus because in order to survive s/he has to transfer his knowledge to the others and be in constant interaction with them." ( $4^{\text {th }}$ year, M)

\subsubsection{Teacher as a Facilitator}

This category embodied 10 metaphors. The most frequently mentioned metaphors were door and key each repeated twice (20\% and 20\%, respectively).

"An EFL teacher is a like a key that opens the doors of the world for [the learners] because s/he can communicate with 
77 nations and by illuminating the ones around her/him she introduces her/his students to all the people in the world." $\left(3^{\text {rd }}\right.$ year, F)

Even though teacher as a mother metaphor mainly referred to the teacher role as a source provider, in one occasion, it served to mean facilitator:

"An EFL teacher is like a mother because teaching is a profession that requires patience and self-sacrifice just like a mother; a new language means a new and a totally different person and the teacher prepares her students to a new future. In this sense she helps them to learn this new culture" $\left(2^{\text {nd }}\right.$ year, F)

The other metaphors used in order to indicate the facilitating role of the teacher were gatekeeper, joint, universal music, communication device and bridge. The pre-service teachers see the role of an EFL teacher as

"An EFL teacher is like universal music because s/he helps people to come together, communicate internationally, and sing the same peace song." ( $3^{\text {rd }}$ year, F)

"An EFL teacher is like a joint because s/he connects two different cultures and while doing so s/he establishes a bond. Without making people feel that these are two different cultures, s/he enables them to fulfill the same task."

$\left(4^{\text {th }}\right.$ year, F)

The metaphors used by participants in this category reflected conceptualizations of language teachers with the ability to develop learning environments in which students can learn key concepts and embrace the new culture they are acquainted with. The teacher's main responsibility is to help learners take the responsibility of their own learning and become a competent communicator in this new language.

\subsubsection{Teacher as an Artist}

The metaphor teacher as an artist was articulated only twice constituting $2.3 \%$ of the whole data set. Even though the second and third year students represented teacher as an artist only once (4\% and 2.6\%, respectively), fourth year level students did not construct an image of a teacher as an artist. The metaphors created by students are as follows;

"An EFL teacher is like a colorful artist because s/he has more roles compared to the other teachers. S/he is the one who transforms students into different shapes in order to teach." ( $3{ }^{\text {rd }}$ year, F)

"An EFL teacher is like an artist because s/he should be creative and have an excellent command of language and just like a painter, s/he should create different paintings from her/his students. S/he should address her/his students by using different colors and paints." ( $2^{\text {nd }}$ year, $\left.\mathrm{F}\right)$

This metaphor implies that if teaching is a creative act, it is plausible to say that teachers are involved in an artistic work. Similar to a painter or a sculptor acting upon their materials, the teachers work with their students in order to create a learning environment that is aesthetically appealing and form them in the same way an artist does.

\subsubsection{Teacher as a Craftsperson}

There are four metaphors (4.6\%) under this category, and the most dominant metaphor is builder appearing two times followed by engineer and carpenter seen only once. Even though the second and fourth year students generated only one metaphor per group (4\% and 4.3\%, respectively), there are two metaphors created by third year students (5.1\%). The metaphors labeled under this category signal the teacher's role as changing students into a predetermined shape. Like a craftsperson, teachers know what materials and tools they have and what they need to do in order to obtain learning outcomes. The main difference between the teacher as an artist or a craftsman is the freedom teachers operate in. While an artist is concerned about the process and product in a more liberal way with a creative spark, a craftsperson is more focused on the product and precision. The teacher as an artist emphasizes emotional dimension whereas teacher as a craftsperson focuses on producing the result s/he seeks. The following quotes exemplifies this distinction.

"An EFL teacher is like a modern and honest engineer, they construct the future of children." ( $3{ }^{\text {rd }}$ year, F)

"An EFL teacher is like a carpenter because he spends time with his students, shapes them and in time reaches perfection and becomes the one and only." ( $4^{\text {th }}$ year, F)

\subsubsection{Teacher as a Direction Setter}

The fifth category of metaphorical representations refers to items that characterize the teacher as a direction setter. Teacher as a direction setter creates visions of teachers who see what is lying ahead and allures others to it. The teacher appears as being responsible for leading students towards their goals and helps them reach the unknown and the "unfamiliar" places. There are $11(12.6 \%)$ metaphors created under this category; second year students generated five metaphors (20\%), third year students three (5.1\%) and fourth year students four (17.4\%). The percentages showed that sophomores envisioned teacher as a direction setter more than junior and senior students did. The recurring metaphors 
were light house (two occurrences), compass (two occurrences), map (two occurrences) followed by candle, cabinet, torch, sun, mother which were voiced only once.

"An EFL teacher is like a compass because during the classes, she illuminates [students] about the places they have never seen and been to and introduces them to unfamiliar cultures." ( $3^{\text {rd }}$ year, F)

"An EFL teacher is like a map, it helps us to discover the unknown places we haven't been to before. (4 ${ }^{\text {th }}$ year, F)

"An EFL teacher is like the cabinet that opens to Narnia because it shows you that there is a different world out there and how you can understand it $\left(2^{\text {nd }}\right.$ year, $\left.\mathrm{M}\right)$

\subsubsection{Teacher as a Superior Authoritative}

The teacher as a superior authoritative implies both involvement and discipline. Rather than the traditional pedagogical view of teacher as an authority who transmits knowledge, teacher as a superior authority refers to teachers who are powerful and unreachable. There are only two metaphors generated under this concept constituting $2.3 \%$ of the data set. The metaphors used to describe teacher as a superior authority are contemporaneity monument (second year $4 \%$ ) and snow on the mountain Everest (fourth year $4.3 \%$ ). Third year students did not attribute such a role to the EFL teacher. Being located on the top and able to detect all the happenings from where they are, teachers are likely to see the minds of students and hierarchically they are set at an upper and superior position. The following quotes render how the participants perceive teacher as a superior authority.

"An EFL teacher is like a contemporaneity monument because s/he knows lots of people, lots of cultures. Her/his viewpoint to life, education (to everything in short) is different. S/he is more open-minded and cosmical." ( $2^{\text {nd }}$ year, F)

"An EFL teacher is like the snow on the mountain Everest because reaching pure, clean and unattainable summits requires constant outstanding effort." $\left(4^{\text {th }}\right.$ year, $\left.\mathrm{M}\right)$

\subsubsection{Teacher as a Change Agent}

An important role teachers play is that of $a$ change agent. In this category, five metaphors were produced. Even though second and third year students created metaphors that pictured the teacher as a change agent $(8 \%$ and $7.7 \%$, respectively), fourth year students did not point to this aspect of teacher. The metaphors created were key (occurring two times) and household appliance, light, and melody each observed once. The concept of teacher as a change agent implies the active developmental role of teachers and their endeavor to help learners discover a new language as well as enabling them to enjoy this new experience.

"An EFL teacher is like a melody that change every environment it enters because it leaves a very nice effect after listening to it." $\left(2^{\text {nd }}\right.$ year, F)

"An EFL teacher is like a key that opens the door to a new life in which you transform into a different person and gain a new persona." ( $3^{\text {rd }}$ year, $\left.\mathrm{F}\right)$

\subsubsection{Teacher as a Nurturer}

This conceptual category encompassed only two metaphors; one generated by a second year student (4\%) and one by a senior student (4.3\%) making up 2.3\% of the data. The metaphors emerged were gardener and tree. These two metaphors depict the teacher's role as that of a cultivator who creates environments where learners can blossom and thrive. This view suggests that teaching is a biotic process that involves providing the students with the necessary conditions to grow and caring for them at the same time.

"An EFL teacher is like a gardener because s/he grows new plants, waters new trees, and prunes them when necessary." ( $2^{\text {nd }}$ year, F)

"An EFL teacher is like a tree because you respect what it gives to you, if you feed it, it will give you more fruits." $\left(4^{\text {th }}\right.$ year, F)

\subsubsection{Teacher as a Counselor}

In this conceptual category, the students assigned the role of a counselor to the teacher by likening the teacher to $a$ personal development specialist and friend. Only third year students attributed this image to the EFL teacher among the participants. Overall, this conceptual category constituted $2.3 \%$ of the data set. This view suggests that the teacher embraces the students as whole persons and the relationship between a teacher and a student is considered as the most essential component of learning.

"An EFL teacher is like a long-distance friend because no matter how far s/he is away from you, s/he understands, listens and always has logical consolation." ( $3^{\text {rd }}$ year, F)

"An EFL teacher is like a personal development specialist because s/he does not only teach a new language but also 
allows us to gain a new personality with this language and enables us to benefit from the culture and accumulation of target language." ( $3^{\text {rd }}$ year, F)

\subsubsection{Teacher as an Entertainer}

There were six metaphors under this category $(6.9 \%)$. The metaphors generated by the third and fourth year students displayed a variation. While junior students preferred to use animator, player and coffee to conceptualize EFL teacher, senior students' metaphors were rainbow, wine, and clown. The teacher was perceived as a person who incorporates humor and entertainment into lessons and creates joy in the classroom while teaching the language. This metaphor resembles the term edutainment according to which the teacher is viewed as an educational entertainer who integrates fun into learning.

"An EFL teacher is like an actor because no matter how unhappy he is, he carries out fun activities with his students. If he is a serious person, he can turn into a joyful one because EFL teachers can act out any role.” ( $3^{\text {rd }}$ year, F).

"An EFL teacher is like an animator because s/he has to attract children's attention and at the same time s/he has to teach them something. S/he should be cheerful all the time.” ( $3^{\text {rd }}$ year, F)

"An EFL teacher is like a colorful clown because s/he has to go from one shape to another, from color to color." $\left(4^{\text {th }}\right.$ year, $\mathrm{F})$

\subsubsection{Teacher as a Cooperative Leader}

The participants produced 11 metaphors under this category making up $12.6 \%$ of the data. Junior and senior students generated metaphors such as bus, plane, adventure, mother, scout, national newspaper, navigation, goalkeeper, petrol, bridge, and coach each appearing once. The teacher and students are reflected in an equal position working collaboratively. While the teacher seems to act like a leader, the students are reflected as partners working towards the achievement of their goals. They take decisions together and share common purposes without being in a hierarchical relationship.

"An EFL teacher is an adventurer because s/he struggles with a new culture, a new language, and the people of this language. On top of that, s/he does not do this alone. S/he makes her/his students her/his fellows. S/he reserves a place for her/his students in this adventure, this language, this culture pool." ( ${ }^{\mathrm{rd}}$ year, F)

"An EFL teacher is like a coach who prepares [students] for a basketball match because s/he plays a vital role for a lot of people and for a great many she simply has the supporting role.” (4 ${ }^{\text {th }}$ year, F)

"An EFL teacher is like a goalkeeper because s/he closes the goal for goals and inserting the ball to the game, s/he directs his/her team friends from behind. S/he is the first person to give the ball for the team game.” $\left(4^{\text {th }}\right.$ year, M)

The classification of teacher candidates' metaphors based on Oxford et al.'s (1998) typology are tabulated below. The following table illustrates the allocation of 11 distinct metaphors according to i. Social Order, ii. Cultural Transmission, iii. Learner-Centered Growth, iv. Social Reform categories.

Table 3. Classification of metaphors according to Oxford et al.'s (1998) typology

\begin{tabular}{|c|c|c|c|c|c|c|c|c|}
\hline \multirow[t]{2}{*}{ Conceptual Categories } & \multicolumn{2}{|c|}{ Sophomores } & \multicolumn{2}{|c|}{ Juniors } & \multicolumn{2}{|c|}{ Seniors } & \multirow{2}{*}{\multicolumn{2}{|c|}{ Total }} \\
\hline & $\boldsymbol{F}$ & $\%$ & $\boldsymbol{F}$ & $\%$ & $\boldsymbol{F}$ & $\%$ & & \\
\hline $\begin{array}{l}\text { Social Order } \\
\text { Craftsman } \\
\text { Superior Authoritative }\end{array}$ & 2 & 8 & 2 & 5.1 & 2 & 8.7 & 6 & 6.9 \\
\hline $\begin{array}{l}\text { Cultural Transmission } \\
\text { Knowledge source } \\
\text { Facilitator }\end{array}$ & 14 & 56 & 20 & 51.3 & 8 & 34.8 & 42 & 48.3 \\
\hline $\begin{array}{l}\text { Learner-centered } \\
\text { Growth }\end{array}$ & 9 & 36 & 11 & 28.2 & 8 & 34.8 & 28 & 32.2 \\
\hline $\begin{array}{l}\text { Artist } \\
\text { Direction Setter } \\
\text { Change Agent } \\
\text { Nurturer } \\
\text { Counselor } \\
\text { Entertainer }\end{array}$ & & & & & & & & \\
\hline $\begin{array}{l}\text { Social Reform } \\
\quad \text { Cooperative Leader }\end{array}$ & - & - & 6 & 15.4 & 5 & 21.7 & 11 & 12.6 \\
\hline Total & 25 & 100 & 39 & 100 & 23 & 100 & 87 & 100 \\
\hline
\end{tabular}


reform (cooperative leader). Pearson chi-squared analysis was undertaken to determine whether there is a significant difference among the frequencies for the factors of metaphor choice and year level. The cutoff point for a p-value was taken as 0.05 . The Chi-Square analysis run on the frequency of cultural transmission and learner-centered growth categories revealed that that there was no significant difference based on different year levels $\left(X^{2}(2, N=87)=2.42\right.$, $\mathrm{p}=.299$ and $\mathrm{X}^{2}(2, \mathrm{~N}=87)=.52, \mathrm{p}=.771$, respectively). This finding suggests that students in three different class levels conceptualized "teacher" statistically in a similar way. As the cells did not have five observations, Chi-square test was not performed on the information cues about social reform and social order categories (Shulman, 1992). Consequently, Fisher's exact test was carried out for these perspectives. Fisher's exact test regarding class level revealed no significant difference in social order $\left(\left(\mathrm{X}^{2}(2, \mathrm{~N}=87)=.65, \mathrm{p}=.761\right)\right.$, but yielded a significant difference in social reform category $\left(\mathrm{X}^{2}(2, \mathrm{~N}=87)=6.26, \mathrm{p}=.043\right)$.

Although there were not statistical differences among the groups in three categories, a closer examination of the percentages shows that while the highest percentage of metaphors insinuate teacher roles comprising cultural transmission $(48.3 \%)$ and learner-centered growth (32.2\%), the lowest percentage of metaphors represents social reform and social order $(12.6 \%$ and $6.9 \%$, respectively). The majority pre-service teachers viewed learners as passive recipients and raw materials to be developed and nurtured. Furthermore, the learner-centered category demonstrates a different pattern. Despite the emphasis on learner-centered growth by second year pre-service EFL teachers (36\%), third year students do not seem to consider this role important (28.2\%) as much as freshman students. However, in the fourth year, students seem to value this aspect more than their third year counterparts. Likewise second year level students possessed more growth and cultural transmission oriented metaphorical images than upper levels while final level students generated more social-reform oriented (21.7\%) metaphors than third level students did (15.4\%).

The metaphors produced were diverse and complex but they were systematized through philosophical paradigms by using a framework. However, to be able to make a more solid interpretation of the data, a cluster analysis was applied to metaphors using k-means algorithm (Hartigan \& Wong, 1979). Because Oxford et al.'s four-part typology makes discrimination between teacher control and shared teacher and student control, two clusters were defined, and these clusters were tested using SPSS statistical program. This procedure permitted separation of the observed values into integral clusters.

Table 4. Final cluster centers

\begin{tabular}{lcc}
\hline & Cluster 1 & Cluster 2 \\
\cline { 2 - 3 } Social Order & .13 & .00 \\
Cultural Transmission & .88 & .00 \\
Learner Centered & .02 & .69 \\
Social Reform & .00 & .28 \\
\hline
\end{tabular}

In my quest to scrutinize the way pre-service EFL teachers' professional identities are developed, segmenting the 87 metaphors based on class level exhibited that they are optimally clustered into two categories. These two categories represent two paradigms that characterize education: teacher centered and learner centered approaches to teaching and learning.

Table 5. Cluster analysis of metaphors

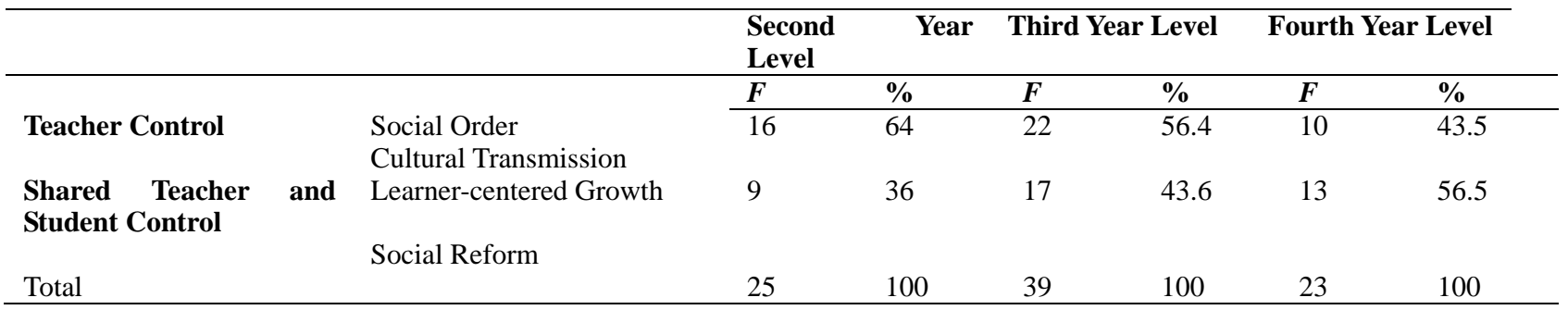

Upon inspecting frequencies and percentages in each cluster, noticeable variations are observed among the groups. There is a gradual decline from $64 \%$ to $56.4 \%$ and finally to $43.5 \%$ in participants' views of teacher as an individual responsible for social order and cultural transmitter as they move from second to fourth year. The decline in teacher control cluster suggests that pre-service EFL teachers tend to alter their vision of teacher mainly adapting a constructivist view of learning. A similar but inverse pattern is seen in the second cluster which emphasizes both teacher and student control over learning and teaching. Even though second year level students seem to value this paradigm less (36\%), there is an increase in the percentage of metaphors throughout the course of development reaching $56.5 \%$ in the final year. They do see the teacher as a knowledge source responsible for transferring knowledge and facilitating learning initially. This perception, however, changes after academic courses are taken and school practices start. The following figure demonstrates how pre-service EFL teachers' perceptions of teacher roles change. 


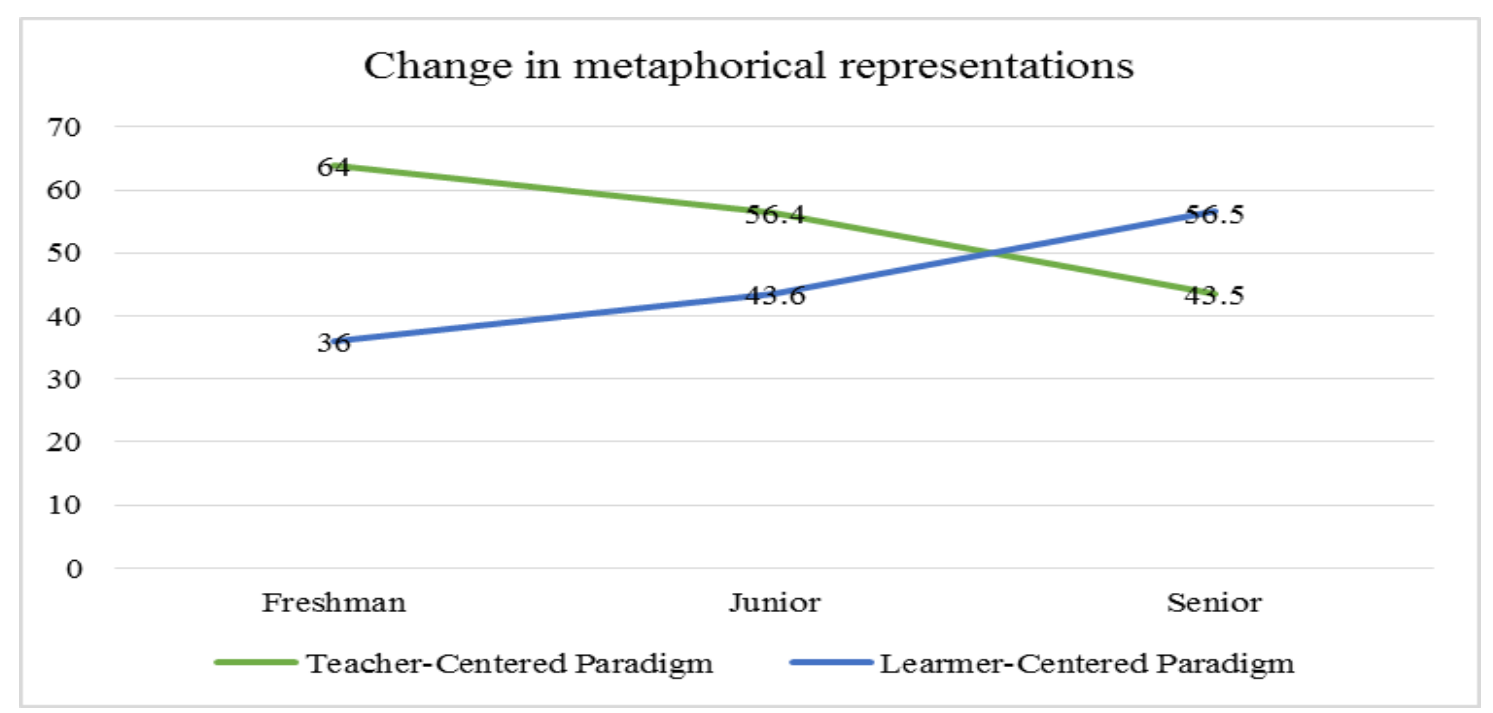

Figure 1. Learner-centered and teacher-centered dichotomy from the point of view of pre-service EFL teachers

The results lend support to the initial assumption about the impact of class level differences on prospective teachers' thinking about teaching and learning. As is evident from the numbers, the movement from a teacher-oriented conception to a learner-oriented denotes a change in favor of learner-centered approach to teaching and learning.

\section{Conclusion and Discussion}

A central aspect of the study outlined here was to investigate to what extent teacher metaphors might change as pre-service EFL teachers move through year levels during their teacher education program, and what this change implies for teacher education. More specifically, the study sought to elicit pre-service teachers' metaphors and how these metaphors can be used to make assumptions about their identity development. The qualitative analysis of the metaphors generated by the participants indicated that the participants had positive perceptions of language teachers. None of them described the teacher negatively comparing the EFL teacher to "a big lorry" which should not be provoked and "a bad song" spoiling the mood as reported by Nikitina and Furuoka (2007). The metaphors produced by the students were diverse; they included images of human beings, abstract images and objects, and were similar to the images generated in other educational contexts, teacher as a mother (Farrell,2006), teacher as nurturer and teacher as provider of knowledge (De Guerrero \& Villamil, 2001). In the present study, teacher as knowledge source was the recurrent metaphor. This finding reveals that pre-service language teachers perceived language teachers as the ultimate possessors of knowledge whose main role is to transfer their knowledge to students. This perception could result from their experiences as pupils and years of experience observing the work of their teachers (Lortie, 1975).

The metaphors teacher as a direction setter, cooperative leader, and facilitator followed the most dominant teacher metaphor teacher as a source of knowledge. Use of a wide range of metaphors indicated that pre-service language teachers attributed diverse roles to the teacher other than assigning the task of transmission of knowledge. The participants described teaching as shaping students into a prescribed model and facilitating learning at the same time. Similar to the findings of previous studies (e.g. de Guerrero \& Villamil, 2001; Saban et al. 2007; Seferoğlu et al. 2009), the metaphorical images of teachers emerged in this study confirmed that teachers have multiple roles which can hardly be condensed into one single metaphor. In Saban et al.'s (2007) study they found that the most dominant themes English education students chose were knowledge provider, molder/craftsperson, facilitator, counselor, cooperative leader and nurturer with a descending percentage. While in their study, teachers were not highly perceived as change agents and entertainer, in this study the respondents identified teachers as change agents and added the role of teacher as an entertainer. Thomas and Beauchamp (2011) argue that the multiplicity of metaphors reflects the vast array of perspectives that new teachers bring to a discussion of the development of their professional identities. The findings confirmed that the development of participants' personal professional knowledge was influenced and altered in a positive way by the experiences they were exposed to over the course of teacher learning (Beijaard et al., 2000; Clandinin \& Connelly, 1995).

In addition, prospective language teachers in this study appeared to view teaching as nurturing, changing/transforming, and entertaining. Contrary to previous studies, the teacher candidates in this study did not associate the roles of repairing, curing with teachers, which mostly signal teacher-centered theoretical perspective (De Guerrero and Villamil, 2001; Lin, Shein \& Yang, 2012). It was also interesting to note that senior and junior level students perceived their role 
as a cooperative leader, an aspect that seems to show divergence with previous research (Oxford et al. 1998; Seferoğlu et al. 2009). The participants of this study seemed to be more aware of the teacher's role as facilitating the creation of a more democratic society in which the teachers cooperate with a community of learners and foster multiple viewpoints (Oxford et al. 1998).

Overall, the findings revealed that participating pre-service teachers of English exhibit an inclination to cleave to learner-centered paradigm more than the teacher-centered paradigm, as they expand their pedagogical knowledgebase and gain experiences through school practices. Their dependence on teacher-centered conceptualization at the beginning might be due to the assumption that in the initial stages of teacher education, it might be natural for pre-service teachers to focus on survival (Zeichner \& Tabachnick, 1981) and holding onto what they are already familiar with. Gradually, the few occurrences of learner-centered metaphors and the predominance of teacher-centered metaphors in the sophomore cohort were replaced with more learner-centered metaphors and a decrease in teacher-centered perspectives was observed in the upper levels similar to the experiences of participants in earlier research (Leavy et al., 2007; Martinez et al. 2001). The transformation in their perception signals the process of constructing their professional identities. This change is indicative of how pre-service teacher's sense of identity is continuously constructed and reconstructed during teacher preparation.

Metaphors that fell into teacher-centered paradigm depicted a notion of learning which was based on behaviorist ideas. According to the behaviorist perspective, the learner is passive and knowledge development is achieved by transfer. Teaching and learning in the old paradigm was considered as a task in which instructors were assumed as experts obliged to transfer knowledge to students (Holt-Reynolds, 2000). On the other hand, the metaphors coded under learner-centered dimension echoes cognitivist and constructivist metaphors in previous studies (Greeno, Collins, \& Resnick, 1996; Martinez et al. 2001.) In this view, knowledge is seen as actively constructed by the learners with the support of teachers. Currently, teacher is not regarded as a source of knowledge, but as a facilitator. According to constructivists, learners play an active role in learning. Teacher candidates' metaphors implicitly resonated the shift from a teacher-centered environment of transmission to a more collaborative student-centered learning environment where discovery and questioning are key strategies for learning (Nunan, 1988). This study showed that that the final year teacher candidates appeared to have a more learner-centered view than second and third year level students. This may be interpreted as pre-service teachers get a more learner-centered perspective as they become more experienced in the field and as they transfer theoretical knowledge into practice. Current foreign language teaching methodologies advocate creating learner-centered classrooms rather than a traditional-teacher centered one. Hence, in language teaching context, it is gratifying to document a tendency towards learner-based instruction in pre-service language teachers.

To a large extent, the results of this study further support the existing evidence about the capability of teacher education to transform beliefs in a desired way (Borg, 2011). This signals the necessity for teacher educators to encourage new entrants to the profession to investigate, reflect, and integrate their experiences as they begin to construct their teaching identity (Leavy et al. 2007). If teacher educators acknowledge and monitor how pre-service teacher candidates construct their professional identities during teacher preparation, they can create situations that allow pre-service candidates to reflect on, and analyze their identity development. An important note to make here is that the development of a professional identity does not automatically occur with experience. There is a need for some form of deliberate action and more attention to raise awareness about professional identity development during teacher education program to ensure that new teachers begin their careers with the appropriate scaffolding. In conclusion, the findings of this study advocate that teacher educators can use metaphor analysis as a means to assist prospective teachers to communicate their views and philosophies about teaching and learning. Metaphors can also serve as a pedagogical tool in teacher education to elicit different assumptions of teaching and learning by delving into beliefs that are not explicit or consciously held (Beijaard, Verloop, and Vermunt 2000).

\section{Further Suggestions and Limitations}

In this study, metaphor was used as a tool "to negotiate and make sense of the creative space between what is personal and what becomes public" (Hunt, 2006, p.317). This endeavor into the process of understanding personal conceptualizations through metaphor elicitation made it evident that metaphor construction is a valuable activity for unmasking pre-service teachers' underlying perceptions. The results of this study urge teacher educators to involve pre-service teachers in a variety of self-reflection opportunities, particularly the use of metaphors, in order to better prepare them for the profession they have chosen to pursue.

Nevertheless, the study has limitations, such as sample size and issues related with self-report. It used a small and a convenient sample of university students from one single institution. With a limited number of participating pre-service EFL teachers, this study might have limitations in generalizing the results as representing all the pre-service language 
teachers' conceptualizations. Secondly, the study dealt with the conceptualizations of pre-service EFL teachers depending on what they say instead of what they do. Hence, the participants' responses cannot be accepted as a genuine reflection of how they will act in the classroom when they start teaching. This limitation can potentially be addressed by future research. Longitudinal studies extending over a longer period can be carried out by using interviews accompanied with observations.

\section{References}

Alger, C. L. (2009). Secondary teachers' conceptual metaphors of teaching and learning: Changes over the career span. Teaching and Teacher Education, 25(5), 743-751. http://dx.doi.org/10.1016/j.tate.2008.10.004

Alsup, J. (2006). Teacher identity discourses: Negotiating personal and professional spaces. New York: Taylor and Francis.

Barone, T., Berliner, D. C., Blanchard, J., Casanova, U., \& McGowan, T. (1996). A future for teacher education: Developing a strong sense of professionalism. In J. Sikula (Ed.), Handbook of research on teacher education, $\left(^{\text {nd }}\right.$ Ed.), (pp.1108-1149). New York: MacMillan.

Beauchamp, C., \& Thomas, L. (2009). Understanding teacher identity: An overview of issues in the literature and implications for teacher education. Cambridge Journal of Education, 39(2), 175-189. http://dx.doi.org/10.1080/03057640902902252

Beijaard, D., Meijer, P. C., \& Verloop, N. (2004). Reconsidering research on teachers' professional identity. Teaching and Teacher Education, 20(2), 107-128. http://dx.doi.org/10.1016/j.tate.2003.07.001

Beijaard, D., Verloop, N., \& Vermunt, J. D. (2000). Teachers' perceptions of professional identity: An exploratory study from a personal knowledge perspective. Teaching and Teacher Education, 16(7), 749-764. http://dx.doi.org/10.1016/S0742-051X(00)00023-8

Beltman, S., Glass, C., Dinham, J., Chalk, B., \& Nguyen, B. H. N. (2015). Drawing identity: Beginning pre-service teachers' professional identities. Issues in Educational Research, 25(3), 225-245.

Ben-Peretz, M., Mendelson, N., \& Kron, F. W. (2003). How teachers in different educational contexts view their roles. Teaching and Teacher Education, 19, 277-290. http://dx.doi.org/10.1016/S0742-051X(02)00100-2

Berelson, B. (1952). Content analysis in communication research. New York: Free Press.

Borg, S. (2006). The distinctive characteristics of foreign language teachers. Language Teaching Research, 10(1), 3-31. http://dx.doi.org/10.1191/13621688061r182oa

Borg, S. (2011). The impact of in-service teacher education on language teachers' beliefs. System, 39(3), 370-380. http://dx.doi.org/10.1191/13621688061r182oa

Brand, M., \& Dolloff, L. (2002). Fantasies and other romanticized concepts of music teaching: A cross-cultural study of Chinese and North American music education students' images of music teaching. International Journal of Music Education, (1), 17-30. http://dx.doi.org/10.1177/025576140203900103

Buchanan, J. (2015). Metaphors as Two-way Mirrors: Illuminating Pre-service to In-service Teacher Identity Development. Australian Journal of Teacher Education, 40(10), 33-50. http://dx.doi.org/10.14221/ajte.2015v40n10.3

Bullough, R. V. (1997). Practicing theory and theorizing practice in teacher education. In J. Loughran and T. Russel (Eds.) Teaching about teaching: Purpose, passion and pedagogy in teacher education, 13-31. London: Palmer Press.

Clandinin, D. J., \& Connelly, F. M. (1995). Teachers' Professional Knowledge Landscapes: Teacher Stories. Stories of Teachers. School Stories. Stories of Schools. Educational Researcher, 25(3), 24-30.

Clarke, M. (2008). Language teacher identities: Co-constructing discourse and community. Clevedon, UK: Multilingual Matters.

Combs, A. W., Blume, R. A., Newman, A. J., \& Wass, H. L. (1974). The professional education of teachers: A humanistic approach to teacher preparation. Boston: Allyn and Bacon.

Cortazzi, M., \& Jin, L. (1996). English teaching and learning in China. Language Teaching, 29(02), 61-80. http://dx.doi.org/10.1017/S0261444800008351

Danielewicz, J. (2001). Teaching selves: Identity, pedagogy, and teacher education. Albany, NY: SIJNY Press.

Darling-Hammond, L., \& Bransford, J. (2005). Preparing teachers for a changing world: What teachers should learn 
and be able to do. San Francisco, CA: Jossey-Bass.

Day, C. (2002). School reform and transitions in teacher professionalism and identity. International Journal of Educational Research, 37, 677-692. http://dx.doi.org/10.1016/S0883-0355(03)00065-X

De Guerrero, M. C., \& Villamil, O. S. (2001). Metaphor analysis in second/foreign language instruction: A sociocultural perspective. Revised version of paper presented at the annual meeting of the American Association of Applied Linguistics, St. Louis, MO, February 24-27, 2001. Retrieved October 9, 2015, from http://files.eric.ed.gov/fulltext/ED461990.pdf

Dolloff, L. A. (1999). Imagining ourselves as teachers: The development of teacher identity in music teacher education. Music Education Research, 1(2), 191-208. http://dx.doi.org/10.1080/1461380990010206

Farrell, T. S. (2006). 'The Teacher Is an Octopus' Uncovering pre-service English language teachers' prior beliefs through metaphor analysis. RELC Journal, 37(2), 236-248. http://dx.doi.org/10.1177/0033688206067430

Farrell, T. S. C. (2011). Exploring the professional role identities of experienced ESL teachers through reflective practice. System, 39, 54-62. http://dx.doi.org/10.1016/j.system.2011.01.012

Feiman-Nemser, S., \& Remillard, J. (1996). Perspectives on learning to teach. In F. Murray (Ed.), The teacher educator's handbook: Building a knowledge base for the preparation of teachers (63-91). San Francisco: Jossey-Bass.

Freer, P. K., \& Bennett, D. (2012). Developing musical and educational identities in university music students. Music Education Research, 14(3), 265-284. http://dx.doi.org/10.1080/14613808.2012.712507

Goldstein, L. S. (2005). Becoming a teacher as a hero's journey: Using metaphor in pre-service teacher education. Teacher Education Quarterly, 32(1), 7-24.

Greeno, J. G., Collins, A. M., \& Resnick, L. B. (1996). Cognition and learning. In D.C. Berliner \& R.C. Calfee (Eds.), Handbook of educational psychology. New York: Macmillan, 15-46.

Hartigan, J. A., \& Wong, M. A. (1979). Algorithm AS 136: A k-means clustering algorithm. Journal of the Royal Statistical Society. Series C (Applied Statistics), 28(1), 100-108. http://dx.doi.org/10.2307/2346830

Holt-Reynolds, D. (2000). What does the teacher do?: Constructivist pedagogies and prospective teachers'. http://dx.doi.org/10.1016/S0742-051X(99)00032-3

Hunt, C. (2006). Travels with a turtle: metaphors and the making of a professional identity. Reflective Practice, 7(3), 315-332. http://dx.doi.org/10.1080/14623940600837467

İnceçay, V. (2015). The Foreign Language Classroom is Like an Airplane, Metaphorical Conceptualizations of Teachers' Beliefs. Turkish Online Journal of Qualitative Inquiry, 6(2), 74-96. http://dx.doi.org/10.17569/tojqi.48011

Isenberg, A. (1963). On defining metaphor. The Journal of Philosophy, 60(21), 609-622. http://dx.doi.org/10.2307/2023555

Jones, M. G., \& Brader-Araje, L. (2002). The impact of constructivism on education: Language, discourse, and meaning. American Communication Journal, 5(3), 1-10.

Kesen, A. (2010). Turkish EFL learners' metaphors with respect to English language coursebooks. Novitas-ROYAL (Research on Youth and Language), 4(1), 108-118.

Knowles, J. G. (1992). Models for understanding pre-service and beginning teachers' biographies: Illustrations from case studies. In I. F. Goodson (Ed.), Studying teachers'lives (99-152). London, UK, \& New York, NY: Routledge.

Knowles, J. G. (1994). Metaphors as windows on a personal history: A beginning teacher's experience. Teacher Education Quarterly, 21, 37-66.

Kramsch, C. (2003). Metaphor and the subjective construction of belief. In P. Kalaja and A. M. Barcelos (Eds.), New Approaches to Research on Beliefs about SLA, Dordrecht: Kluwer, 109-128. http://dx.doi.org/10.1007/978-1-4020-4751-0_5

Lakoff, G., \& Johnson, M. (1980a). Metaphors we live by. Chicago: University of Chicago Press.

Lakoff, G., \& Johnson, M. (1980b). The metaphorical structure of the human conceptual system. Cognitive Science, 4, 195-208. http://dx.doi.org/10.1207/s15516709cog0402_4

Leavy, A. M., McSorley, F. A., \& Boté, L. A. (2007). An examination of what metaphor construction reveals about the evolution of pre-service teachers' beliefs about teaching and learning. Teaching and Teacher Education, 23(7), 1217-1233. http://dx.doi.org/10.1016/j.tate.2006.07.016 
Lin, W. C., Shein, P. P., \& Yang, S. C. (2012). Exploring personal EFL teaching metaphors in pre-service teacher education. English Teaching:Practice and Critique, 11(1), 183-199.

Lombard, M., Snyder-Duch, J., \& Bracken, C. C. (2002). Content analysis in mass communication: Assessment and reporting of intercoder reliability. Human communication research, 28(4), 587-604. http://dx.doi.org/10.1111/j.1468-2958.2002.tb00826.x

Lortie, D. (1975). Schoolteacher: A Sociological Study. London: University of Chicago Press.

Low, G., \& Cameron, L. (1999). Researching and applying metaphor. Cambridge University Press.

Mahlios, M., \& Maxson, M. (1998). Metaphors as structures for elementary and secondary pre-service teachers' thinking. International Journal of Educational Research, 29(3), 227-240. http://dx.doi.org/10.1016/S0883-0355(98)00027-5

Martínez, M. A., Sauleda, N., \& Huber, G. L. (2001). Metaphors as blueprints of thinking about teaching and learning. Teaching and Teacher education, 17(8), 965-977. http://dx.doi.org/10.1016/S0742-051X(01)00043-9

Miles, M. B., \& Huberman, A. M. (1984). Qualitative data analysis: A sourcebook of new methods. California: Sage Publications Inc.

Moser, K. S. (2000). Metaphor analysis in psychology-Method, theory, and fields of application. Forum Qualitative Sozialforschung/Forum: Qualitative Social Research 1(2), Art. 21. http://nbn-resolving.de/urn:nbn:de:0114-fqs0002212

Nikitina, L., \& Furuoka, F. (2008). A language teacher is like...: Examining Malaysian students' perceptions of language teachers through metaphor analysis. Electronic Journal of Foreign Language Teaching, 5(2), 192-205.

Nunan, D. (1988). The learner-centered curriculum: A study in second language teaching. Cambridge: Cambridge University Press. http://dx.doi.org/10.1017/CBO9781139524506

Oktay, Y. B., \& Osam, Ü. V. (2013). Viewing foreign language teachers' roles through the eyes of teachers and students. Hacettepe Üniversitesi Eğitim Fakültesi Dergisi, 44, 249-261.

Olsen, B. (2008). How reasons for entry into the profession illuminate teacher identity development. Teacher Education Quarterly, 35(3), 23-40.

Oxford, R. L., Tomlinson, S., Barcelos, A., Harrington, C., Lavine, R. Z., Saleh, A., \& Longhini, A. (1998). Clashing metaphors about classroom teachers: Toward a systematic typology for the language teaching field. System, 26(1), 3-50. http://dx.doi.org/10.1016/S0346-251X(97)00071-7

Patton, M. Q. (1990). Qualitative evaluation and research methods (2nd ed.). Newbury Park, CA: Sage.

Saban, A. (2004). Giriş düzeyindeki sinif öğretmeni adaylarinin “öğretmen” kavramina ilişkin ileri sürdükleri metaforlar. Türk Eğitim Bilimleri Dergisi, 2(2), 131-155.

Saban, A., Kocbeker, B. N., \& Saban, A. (2007). Prospective teachers' conceptions of teaching and learning revealed through metaphor analysis. Learning and Instruction, 17(2), 123-139. http://dx.doi.org/10.1016/j.learninstruc.2007.01.003

Sachs, J. (2005). Teacher education and the development of professional identity: Learning to be a teacher. In P. Denicolo \& M. Kompf (Eds.), Connecting policy and practice: Challenges for teaching and learning in schools and universities (pp. 5-21). Oxford: Routledge.

Seferoğlu, G., Korkmazgil, S., \& Ölçü, Z. (2009). Gaining insights into teachers' ways of thinking via metaphors. Educational Studies, 35(3), 323-335. http://dx.doi.org/10.1080/03055690802648135

Shulman, L. S. (1992). Toward a pedagogy of cases. In J. H. Shulman (Ed.), Case methods in teacher education (pp.1-30). New York: Teachers College Press.

Şimşek, M. R. (2014). A metaphor analysis of English teacher candidates' pre-and post-course beliefs about language and teaching. Dicle Üniversitesi Ziya Gökalp Eğitim Fakültesi Dergisi, 22, 230-247.

Thomas, L., \& Beauchamp, C. (2011). Understanding new teachers' professional identities through metaphor. Teaching and Teacher Education, 27(4), 762-769. http://dx.doi.org/10.1016/j.tate.2010.12.007

Tobin, K. (1990). Changing metaphors and beliefs: A master switch for teaching?. Theory into Practice, 29(2), 122-127. http://dx.doi.org/10.1080/00405849009543442

Tobin, L. (1989). Bridging gaps: Analyzing our students' metaphors for composing. College Composition and Communication, 40(4), 444-458. http://dx.doi.org/10.2307/358243 
Wallace, S. (2001). Guardian angels and teachers from hell: Using metaphor as a measure of schools' experiences and expectations of General National Vocational Qualifications. International Journal of Qualitative Studies in Education, 14(6), 727-739. http://dx.doi.org/10.1080/09518390110078404

White, B. E., \& Lemieux, A. (2015). Reflecting Selves: Pre-Service Teacher Identity Development Explored Through Material Culture. Learning Landscapes, 9(1), 267-283.

Yeşilbursa, A. (2012). Using metaphor to explore the professional role identities of higher education English language instructors. Procedia-Social and Behavioral Sciences, 46, 468-472.

Zapata, G. C., \& Lacorte, M. (2007). Pre-service and in-service instructors' metaphorical constructions of second language teachers. Foreign Language Annals, 40(3), 521-534. http://dx.doi.org/10.1111/j.1944-9720.2007.tb02873.x

Zeichner, K. M., \& Tabachnick, B. R. (1981). Are the Effects of University Teacher Education"Washed Out" by School Experience? Journal of Teacher Education, 32(3), 7-11. http://dx.doi.org/10.1177/002248718103200302

\section{(c) $\overline{E Y}$}

This work is licensed under a Creative Commons Attribution 3.0 License. 